\title{
ANALISIS KEMAMPUAN REPRESENTASI MATEMATIS SISWA SMP PADA POKOK BAHASAN STATISTIKA
}

\author{
${ }^{1}$ Farid Tri Ribkyansyah, ${ }^{2}$ Yenni, ${ }^{3}$ Dian Nopitasari \\ 1,2,3 Universitas Muhammadiyah Tangerang, Jl. Perintis Kemerdekaan I No. 33, Cikokol, Tangerang, Banten, \\ (021) 55732923 \\ e-mail: faridkiansyah@gmail.com
}

\begin{abstract}
Abstrak
Tujan penelitian ini adalah untuk mendeskripsikan dan menganalisis kemampuan representasi matematis siswa SMP pada pokok bahasan statistika serta mendeskripsikan dan menganalisis kemampuan representasi siswa berdasarkan kemampuan tinggi, sedang dan rendah. Penelitian ini menggunakan metode penelitian kualitatif deskriptif. Hasil tes kemampuan representasi siswa berdasarkan indikator yang diteliti menunjukkan bahwa siswa dapat menggambarkan diagram, grafik atau tabel dari data yang disajikan mencapai 54,28\%, siswa dapat menggunakan model matematis untuk menyelesaikan persoalan matematika mencapai $40,71 \%$, serta siswa dapat menyimpulkan dengan menggunakan katakata atau teks tertulis dari data yang disajikan mencapai $80 \%$. Siswa yang memiliki kemampuan representasi tinggi mampu menyajikan solusi dengan bentuk representasi visual (diagram), model matematis, dan verbal (kata-kata). Siswa yang memiliki kemampuan representasi sedang hanya mampu mnyajikan solusi dengan bentuk representasi visual (diagram) dan verbal (kata-kata), siswa yang memiliki kemampuan representasi rendah hanya menyajikan solusi dengan bentuk representasi visual (diagram).
\end{abstract}

Kata Kunci: Kemampuan Representasi Matematis Siswa

\begin{abstract}
The purpose of this research is to describe and analyze the ability of representation of junior high school students on the subject statistics as well as to describe and analyze the ability of student representation based on high ability, medium and low. The result of the test representation ability of the students based on the indicator under study indicate that the students can describe the diagram, graph or table of data presented reach $54,28 \%$, students can use mathematical model to solve math problems reach 40,71\%, and student can conclude by using words or written text of data presented reach $80 \%$. Students with high representation ability are able to present solution with visual representation (diagram), mathematical models, and verbal (word). Students with medium representation ability are only able to present solutions with visual representation (diagram) and verbal (word). Students with low representation ability can only present solutions using verbal (word).
\end{abstract}

Keywords: mathematical representation abilities

\section{PENDAHULUAN}

Matematika memuat suatu kumpulan konsep dan operasi-operasi, tetapi didalam pengajaran matematika pemahaman siswa mengenai hal-hal tersebut lebih objektif dibandingkan mengembangkan kekuatannya dalam perhitungan-perhitungannya. Guru yang baik akan menjelajahi daerah isi, memperluas hubungan bidang studi serta memperkenalkan siswa hubungannya dengan situasi konkret. Dalam penerapannya guru hanya mengajarkan konsep dan operasi matematika tanpa melakukan hal - hal diatas untuk mencapai tujuan pembelajaran matematika (Hendriana \& Sumarmo, 2014).

Berdasarkan peraturan UU dan tujuan pembelajaran matematika bahwa upaya untuk mengembangkan tujuan pembelajaran matematika dalam kemampuan matematis pada diri 
siswa dalam pembelajaran matematika harus perlu dikembangkan terutama pada kemampuan representasi matematis.

Dilihat dari hasil penelitian Trends in International Mathematics and Science Study (TIMSS) pada tahun 2007 kemampuan representasi matematis siswa masih jauh dari kata memuaskan yang siswa SMP kelas VIII di Indonesia berada pada peringkat 36 dari 49 negara. Hal ini dikarenakan siswa masih belum bisa menyelesaikan soal yang berhubungan dengan kemampuan matematis siswa, sehingga kemampuan tersebut perlu ditingkatkan.

Permasalahan siswa dalam menyelesaikan soal representasi diakibatkan oleh beberapa faktor yang terkait dalam pembelajaran matematika di dalam kelas, diantaranya siswa kurang menguasai soal kemampuan representasi matematis, siswa tidak pernah memperhatikan guru sedang mengajarkan materi, siswa kurang diajarkan oleh guru untuk mengaplikasikan permasalahan matematika dalam kehidupan sehari-hari sehingga siswa tidak dapat mengerjakan soal representasi matematis dengan baik, guru hanya mengajarkan satu diagram saja yaitu diagram sehingga siswa hanya bisa menggambarkan diagram yang telah diajarkan oleh guru.

Melihat uraian di atas siswa belum dapat menguasai soal kemampuan representasi matematis dengan baik, sehingga perlu diadakan penelitian untuk mengetahui kemampuan representasi matematis siswa. Harapannya, penelitian ini dapat menjadikan sumber untuk guru matematika dalam meningkatkan kualitas pembelajaran matematika di sekolah.

Berdasarkan latar belakang yang telah diungkapkan diatas, maka peneliti akan melakukan penelitian yang berjudul "Analisis Kemampuan Representasi Matematis Siswa SMP Pada Pokok Bahasan Statistika Kelas VIII di MTs Negeri 37 Jakarta”.

\section{METODE PENELITIAN}

Penelitian ini dilakukan di MTs Negeri 37 Jakarta, alamat di Jalan Kebon Dua Ratus No. 200, RT 03/06, Kamal, Kalideres, Jakarta Barat. Alasan peneliti melakukan penelitian disekolah ini karena masih banyak siswa yang belum bisa menyelesaikan soal representasi kedalam bentuk diagram, grafik atau tabel. Penelitian ini menggunakan metode kualitatif deskriptif dengan tujuan untuk memperoleh data sehingga mengetahui kemampuan representasi matematis siswa SMP pada pokok bahasan statistika. Prosedur penelitian yang dilakukan peneliti sebagai berikut : 
1. Tahap persiapan

Pada tahap ini, hal yang dilakukan adalah a) Meminta izin kepada kepala MTs Negeri 37 Jakarta untuk melakukan penelitian, b) membuat kisi-kisi instrumen tes kemampuan representasi berdasarkan indikator kemampuan representasi matematis, c) membuat pedoman wawancara, d) melakukan validasi instrumen tes kepada siswa kelas IX, e) menganalisis validasi instrumen tes dengan menggunakan uji validitas dan uji reliabilitas.

2. Tahap Pelaksanaan

Pada tahap ini, hal yang dilakukan adalah a) melakukan instrumen tes kemampuan representasi matematis kepada siswa kelas VIII MTs Negeri 37 Jakarta, b) menganalisis instrumen tes kemampuan representasi siswa kelas VIII MTs Negeri 37 Jakarta, c) memilih subyek penelitian berdasarkan hasil tes matematika siswa kelas VIII dengan cara membagi tiga kemampuan yaitu tinggi, sedang dan rendah dengan menggunakan rumus.

$$
\begin{gathered}
\bar{X}=\frac{\sum x_{i}}{n} \\
S B=\sqrt{\frac{\sum\left(X_{i}-\bar{X}\right)^{2}}{n-1}}
\end{gathered}
$$

Keterangan :

$\bar{X} \quad=$ Rata - Rata

$\mathrm{SB} \quad=$ Simpangan Baku

$n \quad=$ Banmyak data

$x_{i} \quad=$ nilai data ke- I

3. Tahap Analisis data

Pada tahap ini, hal yang dilakukan adalah a) menganalisis hasil tes yaitu membuat penyajian data tes kemampuan representasi matematis, b) menganalisis data wawancara dengan cara mereduksi data (data reduction), display data atau penyajian data, menarik kesimpulan atau verifikasi.

Teknik pengumpulan data yang digunakan adalah tes tertulis dan wawancara. Tes yang digunakan berbentuk soal uraian sebanyak 3 soal yang digunakan untuk penelitian. Sedangkan wawancara digunakan untuk penelitian yang lebih mendalam tentang subyek yang akan diteliti. 


\section{HASIL DAN PEMBAHASAN}

Analisis hasil tes kemampuan representasi matematis ini dilakukan setelah peneliti memberikan soal representasi pada pokok bahasan statistika kepada kelas VIII yang bertujuan untuk mendeskripsikan hasil tes kemampuan representasi matematis siswa. Berikut pemaparan tentang hasil data kemampuan representasi matematis siswa pada pokok bahasan statistika.

\section{Data Hasil Tes}

Tabel 4.1

Persentase Total Per Indikator

\begin{tabular}{|c|l|c|c|}
\hline No & \multicolumn{1}{|c|}{ Indikator } & Frekuensi & Persentase \\
\hline 1 & $\begin{array}{l}\text { Siswa dapat menggambarkan } \\
\text { diagram dari data yang disajikan }\end{array}$ & 76 & $54,28 \%$ \\
\hline 2 & $\begin{array}{l}\text { Siswa dapat menggunakan model } \\
\text { matematis untuk menyelesaikan } \\
\text { persoalan matematika }\end{array}$ & 57 & $40,71 \%$ \\
\hline 3 & $\begin{array}{l}\text { Siswa dapat menyimpulkan dari data } \\
\text { yang disajikan dengan menggunakan } \\
\text { teks tertulis atau kata }\end{array}$ & 112 & $80 \%$ \\
\hline
\end{tabular}

Dari tabel di atas secara keseluruhan dapat disimpulkan bahwa siswa yang menyimpulkan dari data yang disajikan dengan menggunakan kata-kata atau teks tertulis memperoleh persentase yang paling tinggi karena siswa dapat menyusun kata-kata dengan tepat, sedangkan indikator yang mendapatkan persentase rendah terdapat pada soal nomor 2 karena siswa belum mampu menggunakan model matematis untuk menyelesaikan persoalan matematika.

\section{Penentuan Subjek Penelitian}

Berdasarkan nilai hasil tes kemampuan representasi matematis siswa kelas VIII.5 diperoleh hasilnya dengan rata-rata yaitu 62,63 dan simpangan bakunya yaitu 17,85, sehingga didapat siswa yang memiliki tingkat kemampuan representasi tinggi yaitu memiliki nilai $\geq$ 80,48, sedangkan untuk tingkat kemampuan representasi siswa yang sedang yaitu memiliki nilai di antara 44,78 $\leq$ Nilai $<80,48$, dan untuk tingkat kemampuan representasi siswa yang rendah yaitu memiliki nilai $<44,78$. Untuk lebih jelasnya dapat dilihat tabel di bawah ini :

Tabel 4.2

Penentuan Subjek Berdsarkan Hasil Tes

\begin{tabular}{|c|c|c|c|}
\hline Kriteria Pengelompokan & Interval & Nilai & Subjek \\
\hline Nilai $\geq$ Mean + SB & Nilai $\geq 80,48$ & 90 & Tinggi \\
\hline Mean - SB $\leq$ nilai $<$ Mean + SB & $44,78 \leq$ Nilai $<80,48$ & 75 & Sedang \\
\hline Nilai $<$ Mean - SB & Nilai $<44,78$ & 30 & Rendah \\
\hline
\end{tabular}

Prima, Vol. 2, No. 2, Juli 2018, 149 - 155. 


\section{Data Hasil Wawancara Siswa}

a. Siswa dapat menggambarkan diagram dari data yang telah disajikan Semua subjek penelitian baik kemampuan tinggi maupun sedang mampu menggambarkan diagram dari data yang telah disajikan dengan untuk menyelesaikan permasalahan matematika.

b. Siswa dapat menggunakan model matematis untuk menyelesaikan persoalan matematika Siswa yang kemampuan tinggi mampu mengubah soal tersebut ke dalam bentuk model matematis dan, untuk kemampuan sedang dan rendah tidak mampu mengubah soal tersebut kedalam bentuk model matematis.

c. Siswa dapat menyimpulkan data yang disajikan dengan menggunakan kata-kata atau teks tertulis

Siswa yang memiliki kemampuan representasi yang tinggi dapat menginformasikan data sesuai dengan representasi lain yang diberikan berupa diagram lingkaran tentang penjualan mobil kemudian disimpulkan dengan menggunakan kata-kata yang tepat. Sedangkan untuk siswa yang memiliki kemampuan sedang dan rendah dapat menyimpulkan diagram lingkaran tentang penjualan mobil dengan tepat tetapi belum menginformasikan data sesuai dengan representasi yang diberikan.

\section{SIMPULAN DAN SARAN (Heading 1)}

\section{Kemampuan Representasi Matematis Siswa}

Siswa dapat menyimpulkan dengan menggunakan kata-kata atau teks tertulis mendapatkan frekuensi atau persentase yang paling besar dibandingkan indikator lainnya, karena siswa dapat memberikan informasi yang tepat dari representasi lain yang diberikan kemudian disimpulkan dengan kata-kata yang baik dan benar. Sedangkan indikator yang memiliki persentase terendah yaitu soal nomor 2 siswa. belum bisa melibatkan model matematis dari representasi lain yang diberikan untuk menyelesaikan persoalan matematika.

\section{Kemampuan Representasi Siswa Tingkat Tinggi}

Kemampuan representasi siswa berdasarkan tingkat tinggi mampu menyelesaikan soal representasi matematis dengan menyajikan solusi melalui representasi visual (diagram), model matematis, dan verbal (kata-kata) 


\section{Kemampuan Representasi Siswa Tingkat Sedang}

Kemampuan representasi siswa berdasarkan tingkat sedang hanya mampu menyelesaikan soal representasi matematis dengan menyajikan solusi melalui representasi visual (diagram) dan verbal (kata-kata).

\section{Kemampuan Representasi Siswa Tingkat Rendah}

Kemampuan representasi siswa berdasarkan tingkat rendah hanya mampu menyelesaikan soal representasi matematis dengan menyajikan solusi melalui representasi verbal (katakata).

Guru diharapkan mampu membimbing siswa dalam melakukan kegiatan belajar di kelas untuk meningkatkan representasi siswa terutama pada materi statistika, serta harus sering memberikan contoh soal pada materi statistika yang berkaitan dengan kehidupan sehari-hari supaya siswa dapat menyelesaikan persoalan matematika yang diberikan guru. Siswa diharapkan sering memperbanyak mengerjakan latihan soal materi statistika dengan sub bab diagram batang, garis dan lingkaran yang berhubungan dengan kehidupan sehari-hari agar siswa dapat meningkatkan kemampuan representasi matematis.

\section{DAFTAR PUSTAKA}

Arifin, Zainal. (2011). Evaluasi Pembelajaran. Bandung : PT Remaja Rosdakarya.

Dahlan, Jarnawi Afgani. (2011). Analisis Representasi Matematis Siswa SMP dalam

Menyelesaikan Masalah Matematika Kontekstual, [online],

(http://journal.fpmipa.upi.edu/index.php/jpmipa/article/download/273/184, diakses 7 Desember 2016).

Hasratudin. (2014). Jurnal Pembelajaran Matematika Sekarang dan yang akan Datang

Berbasis Karakter, Vol. 1, No. 2.

Hendriana, H \& Sumarmo, U. (2014). Penilaian Pembelajaran Matematika. Bandung: PT Refika Aditama.

Lestari, K.E \& Yudhanegara, M.R. (2015). Penelitian Pendidikan Matematika. Bandung:

PT Refika Aditama.

Murni, Atma. (2013). Peningkatan Kemampuan Representasi Matematis Siswa SMP Melalui Pembelajaran Metakognitif dan Pembelajaran Metakognitif Berbasis Softball Skill, [online], （http://ejournal.unri.ac.id/index.php/JP/article/view/1828, diakses 5 Desember 2016).

Prima, Vol. 2, No. 2, Juli 2018, 149 - 155. 
Ramziah, Siti. (2016). Peningkatan Kemampuan Representasi Matematis Siswa Kelas X2 SMAN 1 Gedung Meneng Menggunakan Bahan Ajar Matriks Berbasis Pendekatan Saintifik. Jurnal Muosharafa, vol.8, Nomor 3.

Rangkuti, Ahmad Nizar. (2011). Representasi Matematis, [online], (http://jurnal.iainpadangsidempuan.ac.id/index.php/JP/article/download/.../150 ， diakses 9 Desember 2016).

Riadi, Edi. (2014). Metode Statistika Parametrik dan Non Parametrik Untuk Penelitian Ilmu Sosial dan Ilmu Pendidikan. Tangerang :PT. Pustaka Mandiri.

Sabirin, Muhammad (2014). Representasi Dalam Pembelajaran Matematika, Vol. 01, No.2 (http://download.portalgaruda.org/article, diakses 6 Desember 2016).

Simanjutak. (2015). Peningkatan Kemampuan Representasi dan Komunikasi Matematis Siswa SMP Pada Materi Transformasi Dengan Strategi Think-Talk-Write Berbantuan Kartu Domino, [online], (http://jurnal.unimed.ac.id/2012/index.php/paradikma/article/view/3355, diakses 6 Desember 2016). 